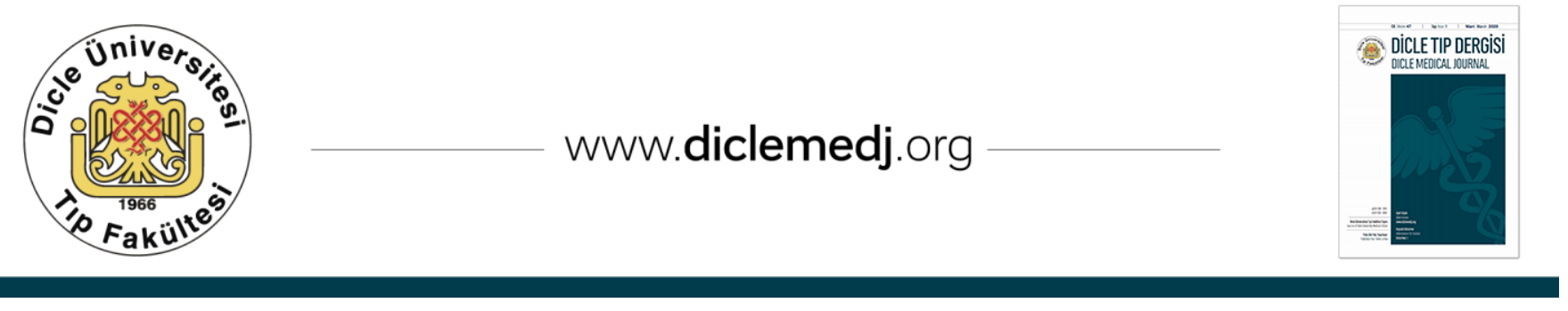

Özgün Araștırma / Original Article

\title{
Santral Sinir Sistemi Tümörlerinin Histopatolojik Dağılımı ve İnsidansı: Tek Merkezin 10 yıllık Retrospektif Analizi
}

\author{
Nesibe Kahraman Çetin1 1 iD \\ 1 Aydın Adnan Menderes Üniversitesi Uygulama ve Araştırma Hastanesi Tıbbi Patoloji Anabilim Dalı, Aydın, Türkiye \\ Geliş: 05.11.2019; Revizyon: 17.01.2020; Kabul Tarihi: 22.01.2020
}

$\ddot{0} \mathbf{z}$

Amaç: Yetişkinlerde Santral Sinir Sistemi (SSS) tümörlerinin insidansı düşük olmasına rağmen, geçen zaman içerisinde tüm dünyada artmaktadır. SSS tümörleri yüksek morbidite ve mortalite oranlarına sahip olup, histolojik tiplerin sıklığı, cinsiyet tercihleri, anatomik lokalizasyonları tüm dünyada farklıdır. Türkiye'de SSS tümörlerinin epidemiyolojisi üzerine birkaç sınırlı çalışma bulunmakta olup, bölgemize ait verileri sunan bir çalışma yoktur. Çalışmanın amacı, Aydın ve çevresi popülasyonda SSS tümörlerinin dağılımını göstermek ve literatür verileriyle karşılatırmaktır.

Yöntemler: Aydın Adnan Menderes Üniversitesi Tıbbi Patoloji Laboratuvarında 2008-2017 yılları arasında tanı alan, primer-metastatik intrakranial tümörleri kapsayan 266 olgu arşivden taranarak çalışmaya alındı. Olguların yaş, cinsiyet, anatomik lokalizasyon, tümör kaynakları, histolojik tipleri ve grade’e göre gruplandırmaları yapıldı.

Bulgular: Erkeklerde kadınlara göre yaş ortalamasının daha büyük olması ( $\mathrm{p}=0.001)$, kadınlarda 40'lı, erkeklerde 60'lı yaşlarda sıklık ( $\mathrm{p}=0,001)$, kadınlarda meningiomların, erkeklerde metastatik tümörlerin daha yüksek oranda görülmesi $(\mathrm{p}=0,002)$, tümör lateralitesinde sağ tarafta sıklık $(\mathrm{p}=0,001)$ anlamlıydı. Primer tümörler en sık frontal lobda, metastatik tümörler en sık serebellumda görüldü ( $\mathrm{p}=0.001)$.

Sonuç: Bu çalışmada primer SSS tümörlerinin cinsiyet, anatomik lokalizasyon, grade dağılımlarının literatür ile uyumlu olduğu, tümörlerin Amerika popülasyonu ile benzer, Asya ve Avrupa popülasyonuna göre daha ileri yaşta görüldügü saptanmıştır. SSS tümör grupları ve histolojik tiplerin dağılımında ise Asya ve Avrupa verilerine daha yakın sonuçlar elde edilmiştir. Tümör lateralitesinin literatürden farklı olarak sağda daha sık olduğu görülmüştür. Metastatik tümörlerin en sık tuttuğu lokalizasyonun serebellum olması ve erkeklerde daha sık olması literatürden farklı elde ettiğimiz sonuçlardır. Bu çalışma, Aydın ve çevresi SSS tümörlerinin epidemiyolojik özelliklerini ve uluslararası serilere kıyasla nasıl dağılım gösterdiğini anlamaya yardımcı olmaktadır.

Anahtar kelimeler: Santral sinir sistemi tümörleri, epidemiyoloji, insidans, primer beyin tümörleri, metastatik beyin tümörleri, Türkiye

DOI: $10.5798 /$ dicletip.706130

Yazışma Adresi / Correspondence: Nesibe Kahraman Çetin, Aydın Adnan Menderes Üniversitesi Uygulama ve Araştırma Hastanesi Tıbbi Patoloji

Anabilim Dalı, Adnan Menderes Üniversitesi Merkez Kampüsü, Kepez Mevkii, Efeler / Aydın, Türkiye e-mail: nesibe.cetin@adu.edu.tr 


\title{
Histopathological Distribution and Incidence of Central Nervous System Tumors: A 10 Years Retrospective Analysis of a Single Center
}

\begin{abstract}
Objective: Although the incidence of Central Nervous System(CNS) tumors in adults is quite low, it has been increasing all over the world. CNS tumors have high morbidity and mortality rates, the prevalence of histological types, gender distribution and anatomical localizations are different worldwide. Although there are a few limited studies available on the epidemiology of CNS tumors in Turkey, there is no study reporting the population of Aydın. The aim of this study is to show distribution of CNS tumors in the population of Aydin and its comparison with International data.

Method: 266 cases of primary-metastatic intracranial tumors which were diagnosed between 2008-2017 in Aydın Adnan Menderes University, Department of Pathology were included in the study. The patients were grouped according to age, sex, anatomical localization, primary/metastatic, histological types and grade.

Results: The mean age in males was higher than in females( $p=0.001)$. The frequency was significant in women of $40-49$ years and men of 60-69 years old $(p=0.001)$. The higher incidence of meningiomas in women, metastatic tumors in men( $p$ $=0.002)$, and right-sided tumors in general $(p=0.001)$ were significant. Frontal lobe originated primary tumors and metastatic tumors situated in the cerebellum were most frequently detected $(\mathrm{p}=0.001)$.

Conclusion: In this study, gender, anatomical localization and grade distributions of primary CNS tumors were consistent with the literature. Age distribution was found to be similar to the American population however, tumors became evident at an older age than they are in the Asian and European populations. Tumor group distribution and histological types were closer to Asian and European data. Right sided tumors were more frequent. This study depicts epidemiological characteristics of CNS tumors in population of Aydın and its comparison with International data.
\end{abstract}

Keywords: central nervous system tumors, epidemiology, incidence, primary brain tumors, metastatic brain tumors, Turkey.

\section{GíRiş}

Santral sinir sistemi (SSS) tümörleri, Dünya Sağlık Örgütü (DSÖ) tarafından sınıflandırılan primer ve metastatik tümörleri kapsayan geniş bir neoplazm serisinden oluşur. Bu tümörler kanser hastalarındaki tüm malignitelerin yaklaşık \%1-2'sini oluşturur'1. Oldukça az görülmekle birlikte, yüksek morbidite ve mortalite oranlarına sahiplerdir. Özellikle anaplastik astrositom ve glioblastom gibi yüksek dereceli tümörlerde beş yıllık yaşam süresi \%5,5-29,7 arasında değişmektedir ${ }^{2,3}$. Diğer tümörlere göre daha kısıtlı kemoterapi olanaklarına sahip olan beyin tümörlerinde, birçoğunun prognozu kötü seyretmektedir. Aynı zamanda psikolojik sağlık ve yaşam kalitesini azaltmaları yanı sıra, nörolojik işlev bozukluğu olan vakaların büyük bir kısmına neden oldukları için, SSS tümörleri klinik araştırmacıların ilgi odağındadır ${ }^{4}$. Son yapılan çalışmalarda tümörlerin oluşum mekanizmaları, altta yatan genetik ve moleküler değişiklikler üzerine odaklanılmış, yeni hedefe yönelik tedavi seçenekleriyle hastaların prognozlarında olumlu gelişmeler olması umut edilmiștir ${ }^{5,6}$.

Primer SSS tümörleri, tüm beyin tümörlerinin \%85-90'inı oluşturur. Metastatik tümörler ise erişkinlerde intrakranial tümörlerin çoğunluğunu oluşturur ve insidansı yaklaşık \%8-10 arasında değişmektedir7,8,9. SSS tümörlerinde histopatolojik sinıflandırma ve gradeleme olguların klinik takip ve tedavi protokollerinin belirlenmesi, prognostik ve prediktif verilerin elde edilmesi açısından oldukça önemlidir. Bu nedenle diğer sistem tümörlerinde olduğu gibi SSS tümörlerinde de DSÖ sınıflaması ve gradelemesi tüm dünyada ve 
ülkemizde en çok kabul gören sistemdir ${ }^{6}$. Bu seride her bir tümörün kendine ait epidemiyolojik özellikleri, lokalizasyonu, morfolojisi, prognozu ve tedavisi yer alır ${ }^{10,11,12}$. Literatüre katkıda bulunan raporlar göstermektedir ki, SSS tümörlerinin histolojik tiplerinin sıklığı, cinsiyet tercihleri, anatomik lokalizasyon durumları tüm dünyada farklılık göstermektedir. Tedavi modaliteleri ve klinik sonuçları yanısıra hastaların sağkalım oranı, özellikle histolojik tip ve anatomik lokalizasyonuna göre değişme eğilimindedir2,13,14. Bu parametrelere ait verileri ortaya koymak gelecek araștırmalar için faydalı olacaktır.

Yetişkinlerde SSS tümörlerinin görülme sıklığı oldukça düşük olmasına rağmen, geçen zaman içerisinde insidansı tüm dünyada artış göstermektedir7. SSS tümörleri hakkındaki kesin istatistiklere erişebilmek; hastalık yükü hakkında genel bilgi sahibi olmak, klinik deneme çalışmalarına yardımcı olmak ve diğer araştırmaları desteklemek için kritik öneme sahiptir ${ }^{15}$. Amerika Birleşik Devletleri'nde $(A B D)$ ve dünyadaki diğer birçok ülkede, SSS tümörleri hakkındaki veriler, yeni teşhis edilmiş tüm kanserler üzerindeki doğru verilerin toplanması ve raporlanması için, tek tip veri standartlarına uyan merkezi kanser kayıtları tarafından toplanmaktadır ${ }^{15,16}$. ABD Merkezi Beyin Tümörleri Kaylt Defteri'nden (Central Brain Tumor Registry of United States CBTRUS) elde edilen 2010 istatistik raporunda bütün SSS tümörleri oranı 100.000'de 47,6 olarak tahmin edilmiştir ${ }^{17}$. CBTRUS 2011- 2015 yılları arası tüm yaş gruplarında 392.982 SSS tümörleri vakası raporu edilmiş olup; bunların 121,277'si malign, 271,705'i ise non-malign tümörler grubundadır. 2019 yılında ise, 26,170'i malign, 60.800'ü non-malign olmak üzere toplam yıllık 86.970 vaka tahmin edilmektedir16. Uluslararası Kanser Araştırma Derneği (İnternational Agency for Research on Cancer - IARC) verilerine göre tüm dünya genelinde 2012 yılında tanı alan beyin ve diğer SSS tümörlerinin yaklaşı olarak 256,213 olduğu, bundan dolayı ölümlerin de yaklaşı olarak 189,382 olduğu bildirilmiștir ${ }^{18}$. Yine Ulusal Kanser Enstitüsü programı olan Surveillance Epidemiology and End Results (SEER) verilerine göre 2011 yllında primer SSS tümörleri görülme sıklığı $6.4 / 100,000$ ve ölüm oranları 4.3/ 100,000 olarak bildirilmiștir6,19. Özellikle sağlık açısından gelişmekte olan ülkelerde bölgesel kanser kayıtları ile yeni tanı alan vakaların toplam kaydının olmaması sebebiyle bu gibi kanserlerin gerçek kanser yükü hakkında net bilgiler yoktur ${ }^{13}$. Ülkemizde SSS tümörlerinin sıklığı ile ilgili istatistikler değişiklik göstermekte olup, gerçek insidans verileri bulunmamaktadır. Otopsi serileri ve kurumsal verilerde hastalar randomize seçilmediğinden, ölüm kayıtlarına dayalı verilerde ise histopatolojik tanı ile korelasyon sağlanmadığından, bu veriler gerçek insidans bilgilerini yansıtmamaktadır. Ülkemizde örneklem büyüklüğü küçük olmasına rağmen, bu tümörlerin epidemiyolojisi hakkında sadece birkaç kurum araştırma yapmıştır ${ }^{20,21}$. Bu çalışma gibi hastane temelli çalışmalar ile kanser yükünün tahmini bazali hakkında bilgi birikimi oluşturulabilir. Türk popülasyonundaki SSS tümörlerinin spektrumunu inceleyen hastane temelli kayit verilerinin üretilmesi, uluslararası yapılanlara benzer şekilde ulusal olarak büyük ölçekli çalışmalara katkıda bulunmamıza yardımcı olacaktır22,23. Ayrıca SSS tümörleri verilerinin önceki ve gelecekteki çalışmalarla ve dünya literatürüyle karşılaştırılması için gerekli klinik verileri sağlayacaktır. Bu veriler sadece ulusun sağllk ve politika ihtiyaçlarını vurgulamakla kalmaz, aynı zamanda akademik araştırmaları SSS tümörlerine yönlendirmede de değerli bilgiler sağlar ${ }^{13,23}$.

Türkiye'de SSS tümörlerinin epidemiyolojisi üzerine birkaç sınırlı ve küçük örneklem grubu şeklinde çalışma bulunmakta olup, bölgemize 
ait verileri sunan bir çalıșma yoktur. Bu çalışma, Aydın Adnan Menderes Üniversitesi Hastanesi Tıbbi patoloji laboratuvarı kayıtlarına dayanan 10 yıllık bir dönemi kapsamaktadır ve merkezi tek hastane temellidir. Burada tanılarını alan olguların sıklığını, ayrıca yaş, cinsiyet, histolojik grup ve tip, grade ve anatomik lokalizasyona göre tümör dağılımını sunmak amaçlanmıştır. Sonuçların Aydın ve çevresi SSS tümörlerinin epidemiyolojisi ile ilgili bilgileri yansitması beklenmekte, ayrıca gelecekteki çalışmalar için bir temel olarak hizmet vermesi düşünülmektedir.

\section{YÖNTEMLER}

$\mathrm{Bu}$ çalışmada Aydın Adnan Menderes Üniversitesi Hastanesi Tibbi Patoloji Laboratuvarında 2008-2017 yılları arasında tanı alan SSS tümörlerine ait patoloji arşiv kayıtları tarandı, olgulara ait tüm veriler arşivlenmiş patoloji raporları gözden geçirilerek elde edildi. Olguların demografik özellikleri, anatomik lokalizasyonu, lezyon tipi, histolojisi ve tümör gradelemesi kaydedildi. Veriler, primer ve metastatik intrakranial tümörleri kapsamakta idi. 10 ylllı süre içerisinde tanı konulan 266 olgu çalışmaya alındı. Aynı olguya ait birden fazla olan, yetersiz doku nedeniyle tanı alamayan patoloji raporları ve 18 yaş altındaki üç olgu çalışmaya dahil edilmedi. Ayrıca SSS'de sık görülen kistik tümörler (Epidermal kist, Araknoid kist, Osseöz kist, sebase kistler) ile hamartomatöz lezyonlar, periferik sinir tümörleri ve spinal kord tümörleri bu olgu serisine dahil edilmedi. Olguların sayı ve oranları belirlenmiş olup, olguların yaş grupları, cinsiyete göre dağılımları, anatomik lokalizasyonları, tümör kaynakları ve histolojik tiplerine göre gruplandırmaları yapıldı. $\mathrm{Bu}$ çalışmada kullanılan SSS tümörleri grupları ve histopatolojik tanıları DSÖ 2007 sınıflamasına dayanarak oluşturuldu. Tümör sinıflaması, çalışmaya dahil edilen olguların mevcut histopatolojik tanıları doğrultusunda 7 ana grupta değerlendirildi: Nöroepitelyal tümörler, Kranial sinir tümörleri, Meningiomlar, Mezenkimal non-meningeal tümörler, Hematopoietik tümörler ve lenfoma, Sellar bölge tümörleri, Metastatik tümörler ${ }^{10}$.

İstatistik çalışmaları SPSS (Statistical Package for Social Sciences) 22.0 Windows programı kullanılarak hesaplandı. Tanımlayıcı istatistiklerde sayı ve yüzde, gruplar arası karşılaştırmalarda Ki kare ve Fisher'in kesin testi, farklılık hesaplamalarında paired samples t-test, korelasyon hesaplamalarında Pearson korelasyon testi kullanıldı. Anlamlılık seviyesi 0,05 alınmış olup, $p$ değerinin $<0,05$ olması durumunda farklılığın istatistiksel olarak anlamlı olduğu belirtildi. Bu çalışma, Aydın Adnan Menderes Üniversitesi Hastanesi Girişimsel olmayan klinik araştırmalar etik kurulunda 2019/17 protokol no ile onaylanmıștır.

\section{BULGULAR}

2008-2017 yılları arasında Aydın Adnan Menderes Üniversitesi Hastanesi Tıbbi Patoloji Anabilim Dalı'nda tanı alan toplam 266 olgu çalışmaya alındı. Vakaların 131'i $(\% 49,2)$ kadın, 135'i (\%50,8) erkek idi. Olguların yaşları 20 ile 89 arasında değișmekteydi. Genel ortalama yaş 60,47 (SD. 14,276) idi. Cinsiyete göre yaş ortalamalarına bakıldığında kadınlarda ortalama yaş 57,84 (SD. 14,840), erkeklerde ortalama yaş 63,02 (SD. 13,269) idi. Erkeklerde kadınlara göre yaş ortalamasının daha büyük olması istatistiksel olarak anlamlı bulundu $(p=0.001, p \leq 0,05)$. SSS'de primer ve metastatik tümörlerin erkeklerde istatistiksel olarak kadınlara göre daha büyük yaşlarda görüldüğü saptandı (sirasıyla $\mathrm{p}=0,017, \mathrm{p}=0,023 ; \mathrm{p} \leq 0,05$ ). SSS tümör grupları ve histolojik tiplerin yaş ortalamalarının cinsiyete göre dağılımı Tablo I'de gösterildiği gibi olup, hematopoietik tümör ve lenfomalar grubu ile metastatik tümörler grubunda erkekler kadınlara göre istatistiksel 
Çetin N.K.

açıdan daha büyük yaş ortalamasına sahip idi (sırasıyla p=0,053, p=0,023; p s0,05) (Tablo I)

Tablo I: SSS tümör grupları ve histolojik tiplerin yaş ortalamalarının cinsiyete göre dağılımı (DSÖ 2007’ye göre)

\begin{tabular}{|c|c|c|c|c|}
\hline SSS tümörleri & K/E (\%) & K/E Ort. Yaş (SD) & N (\%) & Ort. Yaş (SD) \\
\hline 1-Nöroepitelyal Tümörler & $40(44 \%) / 51(56 \%)$ & $\begin{array}{ll}62.20 & (15.688) / 61.61 \\
(15.686) & \end{array}$ & $91(34,2)$ & $61.87(15,602)$ \\
\hline -Diffüz Astrositom & $7(58.3) / 5(41.7)$ & 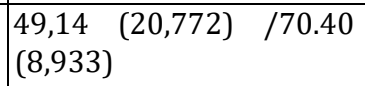 & $12(4,5)$ & $58.00(19,601)$ \\
\hline -Anaplastik astrositom & $3(30) / 7(70)$ & $\begin{array}{ll}61.75 & (15.327) / 53.33 \\
(11.003) & \end{array}$ & $10(3,8)$ & $56.70(12,824)$ \\
\hline -Glioblastom & $20(39.2) / 31(60.8)$ & $\begin{array}{ll}69.38 & (12.679) / 67.00 \\
(9.146) & \end{array}$ & $51(19,2)$ & $67.98(10,687)$ \\
\hline -Oligodendrogliom & $7(77.8) / 2(22.2)$ & $\begin{array}{ll}59 & (9.539) / 63.50 \\
(14849) & \end{array}$ & $9(3,4)$ & $60.00(9,987)$ \\
\hline -Koroid pleksus tümörleri & $0(0) / 2(100)$ & $-/ 44(14.142)$ & $2(0,8)$ & $44(14,142)$ \\
\hline \begin{tabular}{|l|}
-Medulloblastom \\
\end{tabular} & $2(40) / 3(60)$ & $46(0.000) / 26.33(5.508)$ & $5(1,9)$ & $34.20(11,454)$ \\
\hline -Glionöronal tümör (DİG) & $0(0) / 1(100)$ & $-/ 20$ & $1(0,4)$ & 20 \\
\hline -Gangliogliom & $1(100) / 0(0)$ & $81 /-$ & $1(0,4)$ & 81 \\
\hline 2-Kranial sinir tümörleri & $1(33.3) / 2(66.7)$ & $44(0.0) / 66.5(23.335)$ & $3(1,1)$ & $59(21,000)$ \\
\hline -Schwannom & $1(33.3) / 2(66.7)$ & $44(0.0) / 66.5(23.335)$ & $3(1,1)$ & $59(21,000)$ \\
\hline 3-Meningiomlar & 55 (75.3)/18 (24.7) & $\begin{array}{ll}58.62 & (13.405) / 65.5 \\
(12683) & \end{array}$ & $73(27,4)$ & $60.32(13,478)$ \\
\hline $\begin{array}{l}\text { 4-Mezenkimal non-meningeal } \\
\text { tümörler }\end{array}$ & $3(60) / 2(40)$ & $\begin{array}{ll}48.67 & (12.897) / 58.5 \\
(3.536) & \end{array}$ & $5(1,9)$ & $52.60(10,738)$ \\
\hline -Hemanjioperisitom & $1(100) / 0(0)$ & $38 /-$ & $1(0,4)$ & 38 \\
\hline -Sarkom & $2(50) / 2(50)$ & $54(12.728) / 58.5(3.536)$ & $4(1,5)$ & $56.25(8,057)$ \\
\hline $\begin{array}{l}\text { 5-Hematopoietik tümörler ve } \\
\text { lenfoma }\end{array}$ & $2(28.6) / 5(71.4)$ & $56(15.556) / 76.8(6.221)$ & $7(2,6)$ & $70.86(13,005)$ \\
\hline
\end{tabular}

Tablo II: SSS tümörlerinin 10’lu yaş gruplarına göre dağılımı

\begin{tabular}{|c|c|c|}
\hline 10'lu yaş grupları & K/E & N (\%) \\
\hline $20-29$ yaş aralığı & $2 / 4$ & $6(2,3)$ \\
\hline $30-39$ yaş aralığı & $11 / 3$ & $14(5,3)$ \\
\hline $40-49$ yaş aralığı & $29 / 8$ & $37(23,7)$ \\
\hline $50-59$ yaş aralığı & $30 / 33$ & $63(23,7)$ \\
\hline $60-69$ yaş aralığı & $26 / 43$ & $69(25,9)$ \\
\hline $70-79$ yaş aralığı & $20 / 32$ & $52(19,5)$ \\
\hline $80-89$ yaş aralığ 1 & $13 / 12$ & $25(9,4)$ \\
\hline Toplam & $131 / 135$ & $266(100)$ \\
\hline
\end{tabular}

SSS tümörlerinin 10 'lu yaş gruplarına göre dağılımına bakıldığında frekansın 40'lı yaşlarda artmaya başladığı, 50'li yaşlarda yükseldiği, 60 'lı yaşlarda pik yaptığı, 70'li yaş gruplarında yüksek oranın devam ettiği, 80 yaş ve sonrası grupta azalma gösterdiği görüldü. (Tablo II)

10 'lu yaş gruplarının cinsiyete göre dağılımına bakıldığında tümörlerin 40 'lı ve 50'li yaşlarda kadınlarda, 50'li ve 60'li yaşlarda ise erkeklerde daha yüksek oranda olduğu görüldü. Kadınlarda 40'lı yaşlarda, erkeklerde ise 60'lı yaşlarda slklık anlamlı idi $(\mathrm{p}=0,001)$ (Şekil 1). 


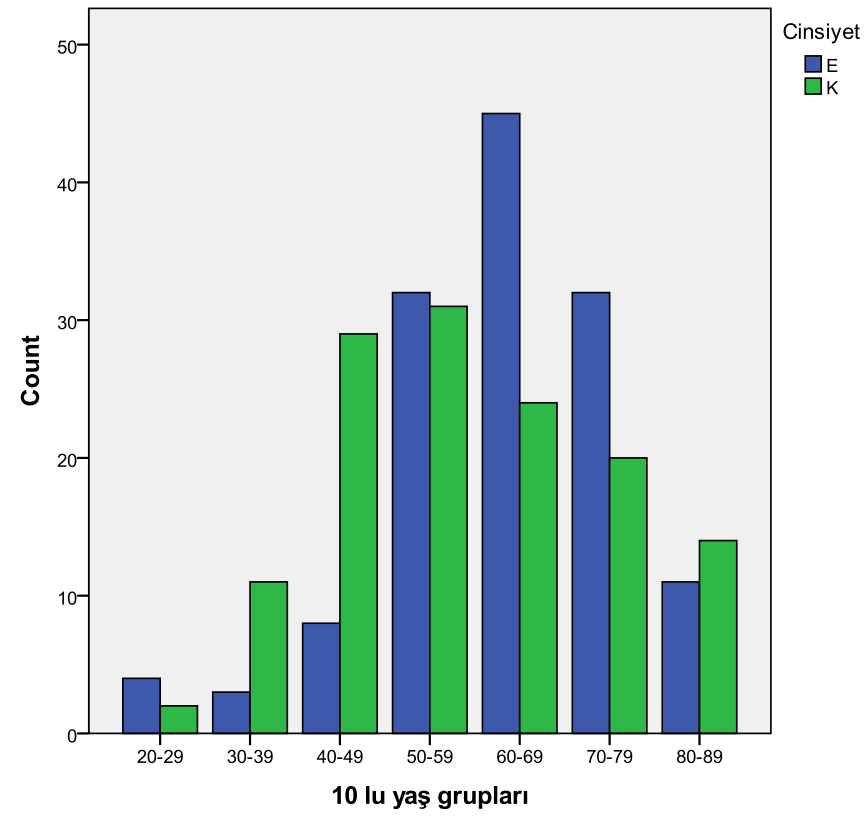

Şekil 1: SSS tümörlerinin 10’lu yaş gruplarının cinsiyete göre grafiksel dağılımı

\section{SSS Tümör Grupları}

SSS tümör grupları dağılımına bakıldığında nöroepitelyal tümörler $(\% 34,2)$ en yaygın grup olup, bunu sirasiyla meningiomlar $(\% 27,4)$, metastatik tümörler $(\% 24,4)$, sellar bölge tümörleri $(\% 8,3)$, hematopoietik tümörler ve lenfoma $(\% 2,6)$, mezenkimal non-meningeal tümörler $(\% 1,9)$ ve kranial sinir tümörleri $(\% 1,1)$ izlemekteydi (Şekil 2).

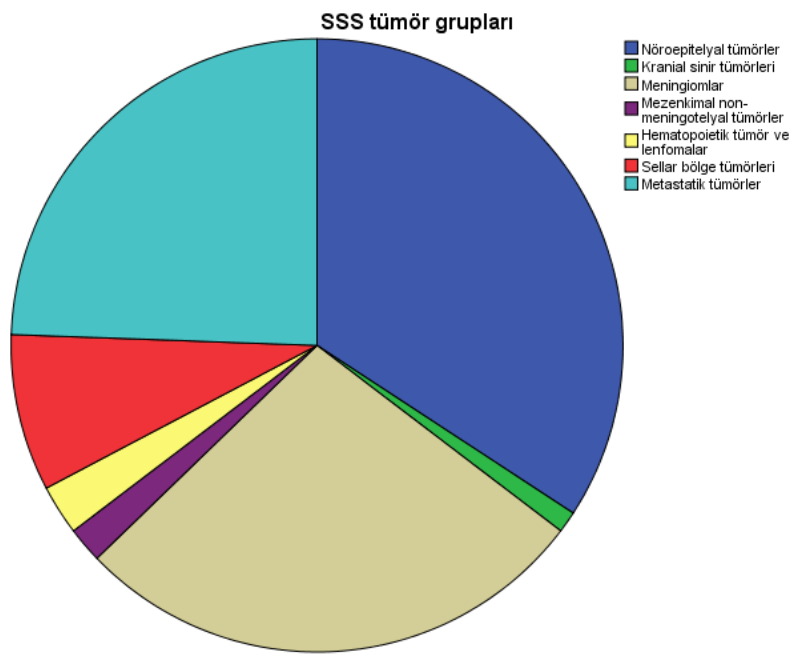

Şekil 2: SSS tümör gruplarının şematik dağılımı (DSÖ 2007’ye göre)
SSS tümör gruplarının 10'lu yaş gruplarına göre dağılımına bakıldığında nöroepitelyal tümörler, meningiomlar ve metastatik tümörlerin 60'lı yaşlarda daha sık olduğu görüldü $(p=0,023)$.

SSS tümörleri gruplarının cinsiyete göre dağılımına bakıldığında kadınlarda meningiomlar (55 vaka, \%42), nöroepitelyal tümörler (40 vaka, \%30,5) ve metastatik tümörlerin (19 vaka, \%14,5), erkeklerde ise nöroepitelyal tümörler (51 vaka, \%37,8), metastatik tümörler (46 vaka, \%34,1) ve meningiomlar (18 vaka, \%13,3) en sık görülen gruplar olduğu saptand. Kadınlarda meningiomların, erkeklerde metastatik tümörlerin diğer cinsiyete göre daha yüksek oranda görülmesi istatistiksel olarak anlamlı bulundu ( $\mathrm{p}=0.001)$ (Şekil 3).

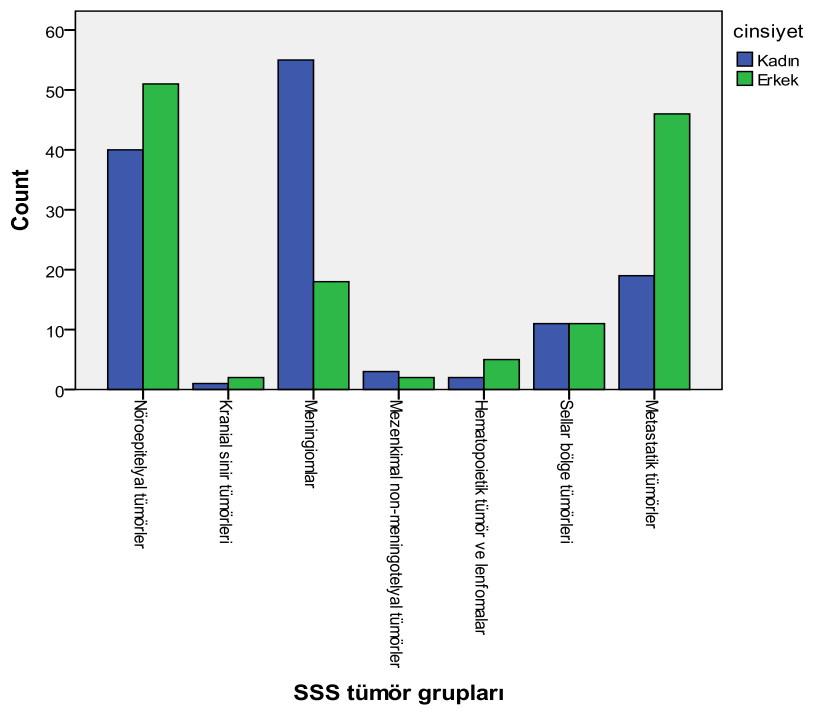

Şekil 3: SSS tümör gruplarının cinsiyete göre grafiksel dağılımı

\section{SSS Tümörleri Histolojik Tipler}

Histolojik tiplere göre primer SSS tümörleri dağılımına bakıldığında en sık görülen histolojik tipin meningiomlar (73 vaka, \%36,3) olduğu görüldü. Bunu glioblastom (51 vaka, \%25,3), hipofiz adenomları (21 vaka, \%10,4), diffüz astrositomlar (12 vaka, \%5,9) ve anaplastik astrositomlar (10 vaka, \%4,9) takip etmekte idi. Primer SSS tümörleri histolojik tiplerin cinsiyete göre dağılımına bakıldığında 
kadınlarda en sık görülen tümörler sırasıyla meningiom (55 vaka, \%27,3), glioblastom $(20$ vaka, $\% 9,9)$ ve hipofiz adenomu (10 vaka, $\% 4,9$ ) iken, erkeklerde en sık görülen tümörler glioblastom (31 vaka, \%15,4), meningiom (18 vaka, $\% 8,9)$ ve hipofiz adenomu (11 vaka, \%5,4) idi.

Tüm SSS tümörleri histolojik tiplerin dağılımına bakıldığında en sık görülen tipin meningiomlar (73 vaka, \%27,4) olduğu, bunu metastazlar (65 vaka, \%24,4) ve glioblastomların (51 vaka, $\% 19,2)$ takip ettiği görüldü. Histolojik tiplerin cinsiyete göre dağılımına bakıldığında kadınlarda en sık görülen tümörlerin sırasıyla meningiom (55 vaka, \%20,7), glioblastom (20 vaka, $\% 7,5$ ) ve metastazlar (19 vaka, $\% 7,1$ ) olduğu, erkeklerde ise metastazlar (46 vaka, $\% 17,3$ ), glioblastom (31 vaka, \%11,7) ve meningiom (18 vaka, \%6,8) olduğu görüldü (Şekil 4).

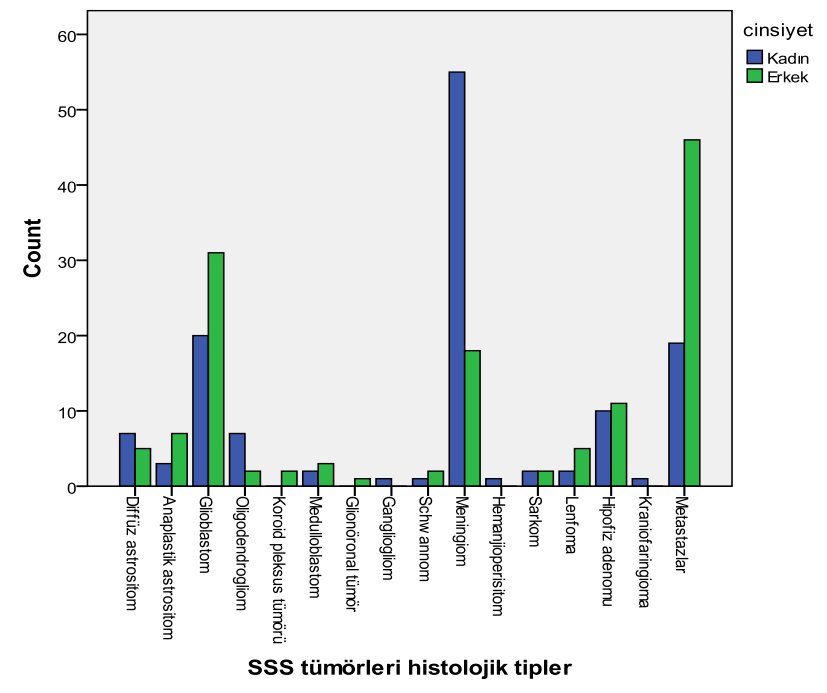

Şekil 4: SSS tümörleri histolojik tiplerin cinsiyete göre grafiksel dağılımı

\section{Anatomik Lokalizasyon}

Anatomik lokalizasyon tentoriyuma göre iki ana bölgeye ayrıldığında $227 \quad(\% 85,3)$ vakada tümörün supratentoriyal bölgede olduğu, 39 $(\% 14,7)$ vakada ise infratentoriyal bölgede olduğu görüldü $(\mathrm{p}=0.001)$. Supratentoriyal bölgede en sık tutulan alan frontal lob (51 vaka, $\% 19,2$ ) olup, bunu pariyetal lob (45 vaka, $\% 16,9)$ ve temporal lob (26 vaka, \%9,8) takip etmekte idi. İnfratentoriyal bölgede en sik tutulan alan serebellum (23 vaka, \%8,6) olup, diğerleri sırasıyla kafa tabanı (14 vaka, \%5,3), posterior fossa (5 vaka, \%1,9) idi (Şekil 5).

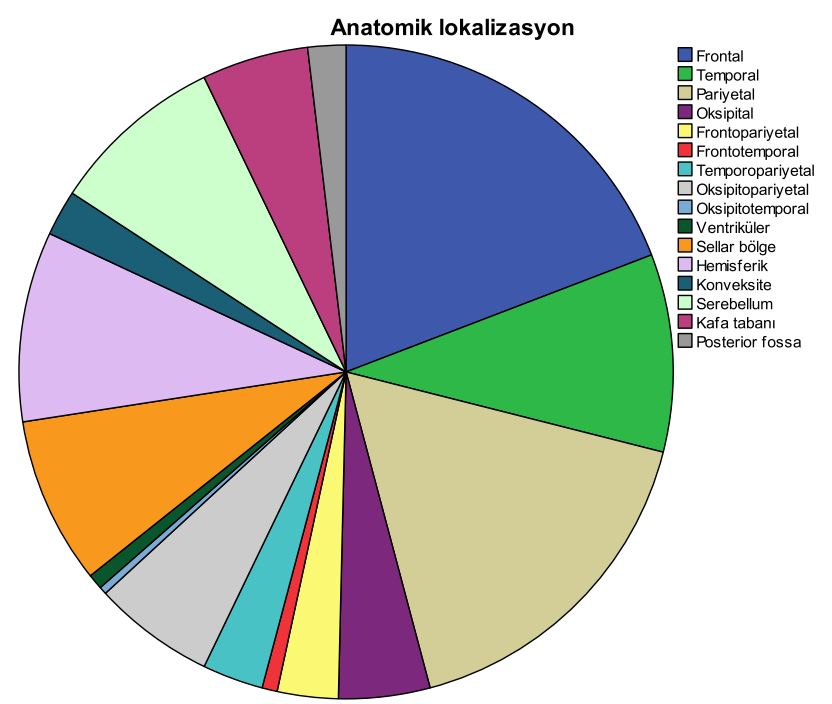

Şekil 5: SSS tümörlerinin anatomik lokalizasyona göre şematik dağılımı

Tentoriyal duruma göre SSS tümör gruplarının dağılımına bakıldığında supratentoriyal bölgede en sık nöroepitelyal tümörler (84 vaka, $\% 37,5) \quad(\mathrm{p}=0,001)$, meningiomlar (55 vaka, $\% 24,6)$, metastatik tümörlerin (50 vaka, $\% 22,3)$, infratentoriyal bölgede ise meningiomlar (18 vaka, \% 42,9), metastatik tümörler (15 vaka, \%35,7) ve nöroepitelyal tümörlerin (7 vaka, \%16,7) görüldüğü saptandı.

En sık görülen SSS tümör gruplarının anatomik lokalizasyona göre dağılımına bakıldığında nöroepitelyal tümörler en sik pariyetal (23 vaka, $\% 25,3)$, frontal (16 vaka, \%17,6) ve temporal (10 vaka, \%11,0) bölgede, meningiomlar en sık frontal (23 vaka, \%31,5), kafa tabanı (12 vaka,16,4) ve temporal ( 9 vaka, $\% 12,3$ ) bölgede, metastatik tümörlerin ise en sık serebellum (15 vaka, \%23,1), frontal (10 vaka, $\% 15,4)$, pariyetal (10 vaka, $\% 15,4)$ ve 
oksipital (7 vaka, \%10,8) bölgede görüldüğü saptandl.

En sık tutulan anatomik lokalizasyonlarda SSS tümör gruplarının dağılımına bakıldığında; frontal lobda (23 vaka, \%31,5) en sik meningiomlar, temporal (10 vaka, \%11) ve pariyetal (23 vaka, \%25,3) lobda en sık nöroepitelyal tümörler, serebellumda en sık metastatik tümörler (15 vaka, $\% 23,1$ ) görüldü $(\mathrm{p}=0,002)$. (Tablo III)

SSS tümörleri histolojik tiplerin tentoriyuma göre dağılımına bakıldığında supratentoriyal bölgede en sık görülen tümör tipleri meningiom (55 vaka, \%24.6), glioblastom (50 vaka, \%22,3), metastazlar (50 vaka, \%22.3) iken, infratentoriyal bölgede en slk görülen tümör tipleri meningiom $(18, \% 42,9)$, metastazlar (15,
$\% 35,7)$ ve medulloblastom $(5, \% 11,9)$ idi. Her iki bölgede en sık meningiomun görülmesi istatistiksel olarak anlamlı bulundu ( $\mathrm{p}=0.001)$.

En sık görülen SSS tümörleri histolojik tiplerin anatomik lokalizasyona göre dağılımına bakıldığında glioblastomlar en sık pariyetal lobda (15 vaka, \%33,3), meningiomlar en sık frontal lobda (23 vaka, \%45,1), metastazlar en slk serebellumda (15 vaka, \%65,2) görüldü. Meningiomların en sık frontal lobda, metastazların en sık serebellumda görülmesi istatistiksel olarak anlamlı bulundu ( $\mathrm{p}=0.001)$.

Tablo III: SSS tümör gruplarının anatomik lokalizasyonuna göre dağılımı

\begin{tabular}{|c|c|c|c|c|c|c|c|c|}
\hline Anatomik lokalizasyon & $\begin{array}{c}\text { NET } \\
n=91 \\
(\% 34.2)\end{array}$ & $\begin{array}{c}\text { KST } \\
n=3 \\
(\% 1.1)\end{array}$ & $\begin{array}{c}\text { MT } \\
n=73(\% 27.4)\end{array}$ & $\begin{array}{c}\text { MNGT } \\
n=5(\% 1.9)\end{array}$ & $\begin{array}{c}\text { HT ve L } \\
n=7(\% 2.6)\end{array}$ & $\begin{array}{c}\text { SBT } \\
\mathrm{n}=22 \\
(\% 8.3)\end{array}$ & $\begin{array}{c}\text { Met } \\
n=65 \\
(\% 24.4)\end{array}$ & $\begin{array}{l}\text { Toplam } \\
n=266 \\
(\% 100)\end{array}$ \\
\hline \multicolumn{9}{|c|}{ Supratentoriyal bölge: $n=227(\% 85,3)$} \\
\hline Frontal & $16(\% 17.6)$ & - & $23(\% 31.5)$ & - & $2(\% 28.6 \%)$ & - & $\begin{array}{c}10 \\
(\% 15.4)\end{array}$ & $51(\% 19.2)$ \\
\hline Temporal & $10(\% 11.0)$ & - & $9(\% 12.3)$ & $1(\% 20.0)$ & $1(\% 14.3)$ & - & $5(\% 7.7)$ & $26(\% 9.8)$ \\
\hline Pariyetal & $23(\% 25.3)$ & - & $8(\% 11.0)$ & $1(\% 20.0)$ & $3(\% 42.9)$ & - & $\begin{array}{c}10 \\
(\% 15.4)\end{array}$ & $45(\% 16.9)$ \\
\hline Oksipital & $3(\% 3.3)$ & - & $2(\% 2.7)$ & - & - & - & $7(\% 10.8)$ & $12(\% 4.5)$ \\
\hline Frontopariyetal & $4(\% 4.4)$ & $1(\% 33.3)$ & $3(\% 4.1)$ & - & - & - & - & $8(\% 3.0)$ \\
\hline Frontotemporal & - & - & 0 & $1(\% 20.0)$ & - & - & $1(\% 1.5)$ & $2(\% 0.8)$ \\
\hline Temporopariyetal & $5(\% 5.5)$ & - & $1(\% 1.4)$ & - & $1(\% 14.3)$ & - & $1(\% 1.5)$ & $8(\% 3)$ \\
\hline Oksipitopariyetal & 9 (\%9.9) & - & $3(\% 4.1)$ & $1(\% 20.0)$ & - & - & $3(\% 4.6)$ & $16(\% 6)$ \\
\hline Oksipitotemporal & - & - & - & - & - & - & $1(\% 1.5)$ & $1(\% 0.4)$ \\
\hline Ventriküler & $2(\% 2.2)$ & - & - & - & - & - & - & $2(\% 0.8)$ \\
\hline Sellar bölge & - & - & - & - & - & $\begin{array}{c}22(\% 100 \\
)\end{array}$ & - & $22(\% 8.3)$ \\
\hline Hemisferik & $12(\% 13.2)$ & - & $1(\% 1.4)$ & $1(\% 20.0)$ & - & - & $\begin{array}{c}11(\% 16.9 \\
)\end{array}$ & $25(\% 9.4)$ \\
\hline Konveksite & - & - & $5(\% 6.8)$ & - & - & - & $1(\% 1.5)$ & $6(\% 2.3)$ \\
\hline
\end{tabular}




\section{Tümör Lateralitesi}

Tümör lateralitesine göre dağılımı yapılan toplam 244 vakanın 155 'inin $(\% 63,5)$ sağ taraf, 89'unun $(\% 36,5)$ sol taraf yerleşimli olduğu görüldü $(p=0,001)$. (Orta hat kabul edilen sellar bölge yerleşimli olan 22 tümör vakası dahil edilmedi.) Lateralite duruma göre SSS tümör grupları dağılımına bakıldığında sağ hemisferde en sık nöroepitelyal tümörler (61 vaka, \%39,4), metastatik tümörler (47 vaka, \%30,3) ve meningiomların (36 vaka, \%23,2), sol hemisferde en sik meningiomlar (37 vaka, \%41,6), nöroepitelyal tümörler (30 vaka, $\% 33,7$ ) ve metastatik tümörlerin (18 vaka, $\% 20,2$ ) görüldüğü saptandı. (Şekil 6)

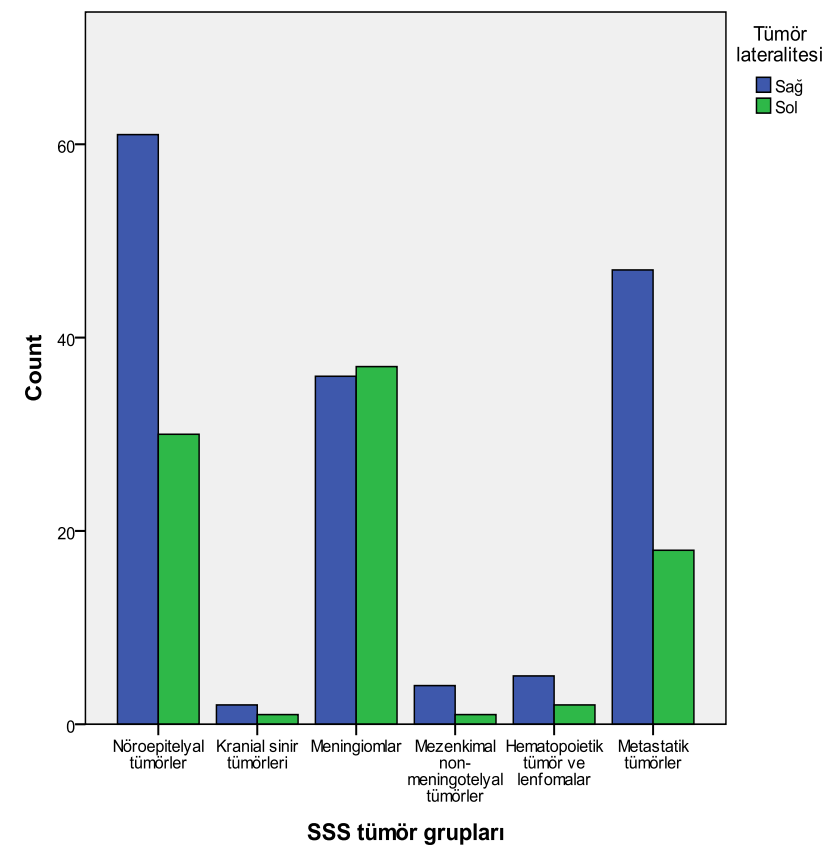

Şekil 6: SSS tümör gruplarının lateralite durumuna göre grafiksel dağılımı

Lateralite durumuna göre tutulan anatomik lokalizasyonların dağılımına bakıldığında sağda en slk pariyetal lob (38 vaka, \%24,5), frontal lob (31 vaka, \%20) ve serebellumun (16 vaka, $\% 10,3)$, solda en slk frontal lob (20 vaka, $\% 22,5)$, temporal lob (11 vaka, \%12,4) ve kafa tabanının (10 vaka, \%11,2) tutulduğu saptandı (Şekil 7).

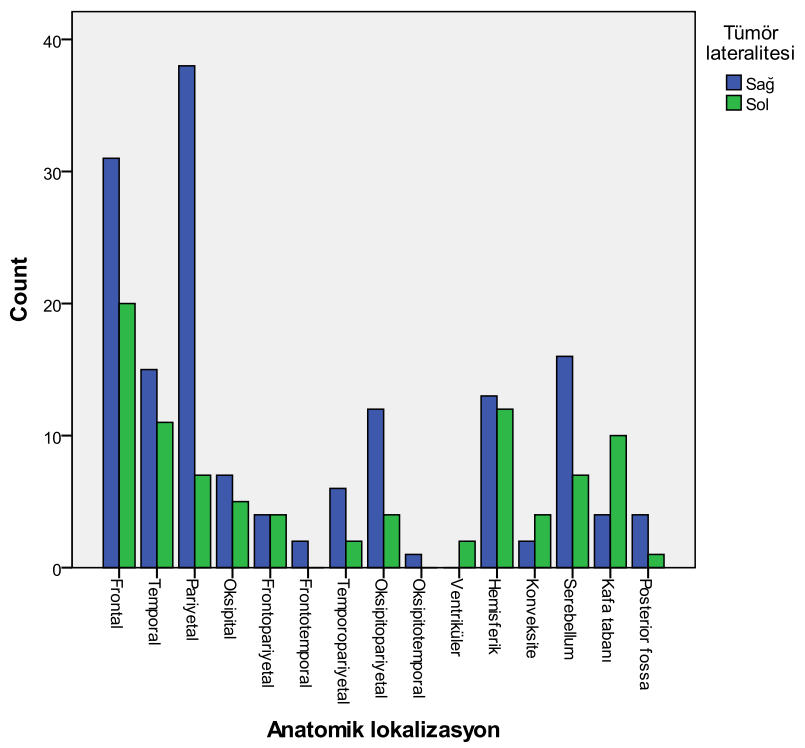

Şekil 7: Anatomik lokalizasyonun lateralite durumuna göre grafiksel dağılımı

\section{Grade}

Primer SSS tümörlerinin grade'e göre dağılımına bakıldığında toplam 194 vakadan $100(\% 51)$ olgunun grade I, 19 (\%10) olgunun grade II, 15 (\%8) olgunun grade III, 60 (\%31) olgunun grade IV olduğu görüldü (Șekil 8).

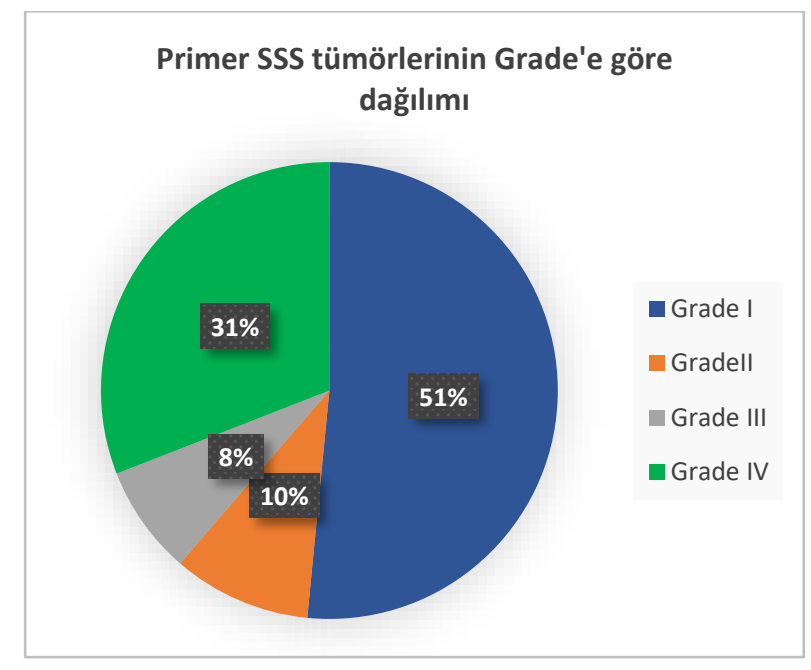

Şekil 8: Primer SSS tümörlerinin Grade'e göre şematik dağılımı

Grade'in cinsiyete göre dağılımına bakıldığında kadınlarda en sık grade I tümörler (69 vaka, $\% 35,5)$, erkeklerde en sık grade IV tümörler (36 vaka, \%18,5) görüldü. Genel dağılıma bakıldığında Grade I ve II tümörler kadınlarda, 
Grade III ve IV tümörler erkeklerde daha sık idi (Şekil 9).

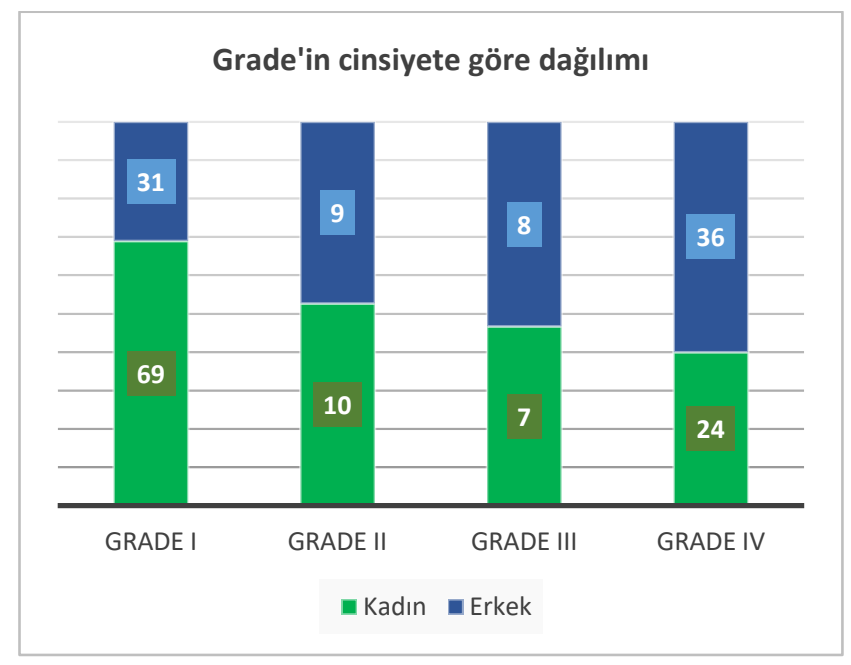

Şekil 9: Grade'in cinsiyete göre grafiksel dağılımı

Primer SSS tümörlerinde Grade'in 10'lu yaş gruplarına göre dağılımına bakıldığında grade I tümörlerin daha erken yaşlarda, grade IV tümörlerin daha ileri yaş gruplarında görülme sıklıklarının arttığı saptandı. (Şekil 10)

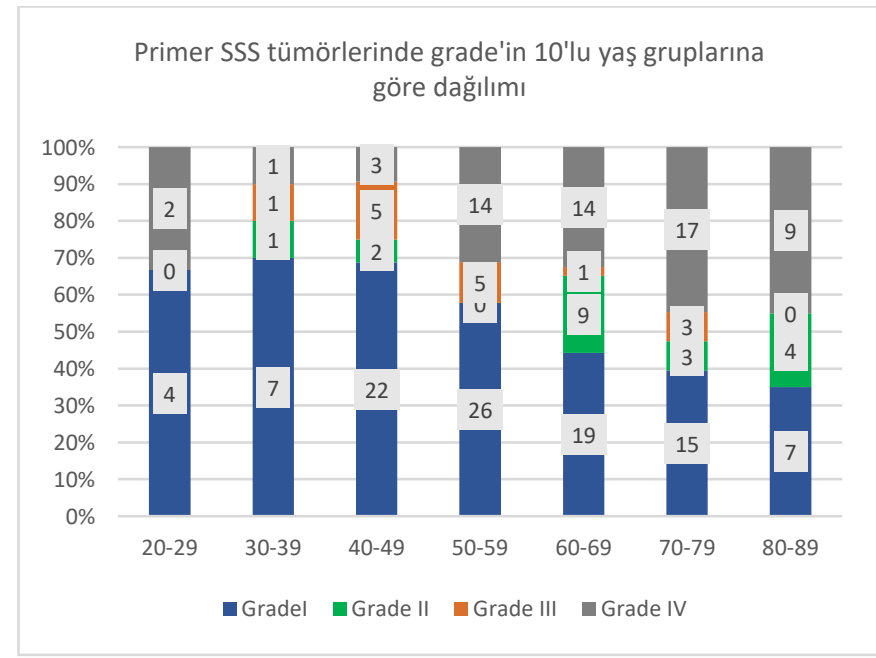

Şekil 10: Primer SSS tümörlerinde Grade'in 10’lu yaş gruplarına göre dağılımı

Grade'in SSS tümör gruplarına göre dağılımında; Grade I tümörler sıklıkla meningiomlar (64 vaka, \%64) iken, diğer grade tipleri sıklıkla nöroepitelyal tümörlerden (Grade II, 10 vaka, \%52,6) (Grade III, 14 vaka, \%93,3) (Grade IV, 56 vaka, \%93,3) oluşmakta idi. Grade'in anatomik lokalizasyona göre dağılımına bakıldığında frontal (21 vaka, \%21) ve temporal lobda (8 vaka, \%8) en sık Grade I tümörler, pariyetal lobda (16 vaka, \%26,7) ise en sık Grade IV tümörler izlendi.

\section{SSS Tümör Kaynağı}

SSS tümörlerinin ana kaynaklarına göre dağılımına bakıldığında 201 (85.3\%) olgunun primer tümör, 65 (24.4\%) olgunun metastatik tümör olduğu görüldü. 201 primer tümör olgusundan 174 tanesi supratentoriyal 27'si infratentoriyal, metastatik tümörlerin ise 50 tanesi supratentoriyal, 15 tanesi infratentoriyal yerleşimli idi $(p=0.64)$. Tümör kaynak tipine göre lokalizasyon dağılımına bakıldığında primer tümörler en sik frontal lobda (41 vaka, $\% 20,4)$, pariyetal lobda (35 vaka, \%17,4) ve temporal lobda $(21$ vaka, $\% 10,4)$ gözlenirken, metastatik tümörler ise en sık serebellumda (15 vaka, $\% 23,1)$, frontal lobda (10 vaka, $\% 15,4)$ ve pariyetal lobda (10 vaka, \%15,4) görüldü. Primer tümörlerin en sik frontal lobda, metastatik tümörlerin en slk serebellumda görülmesi istatistiksel olarak anlamlı bulundu $(\mathrm{p}=0.001)$. (Şekil 11)

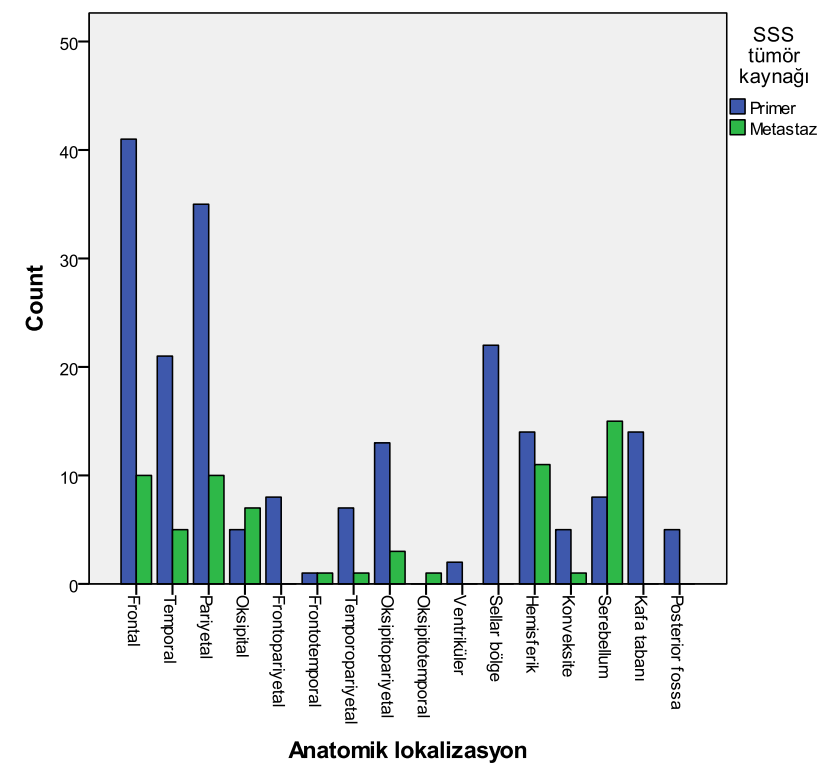

Şekil 11: Primer ve metastatik tümörlerin anatomik lokalizasyona göre grafiksel dağılımı 
Cinsiyetlere göre SSS tümörlerin kaynak dağılımına bakıldığında primer tümörler kadınlarda (112 vaka, \%85,5), metastatik tümörler erkeklerde (46 vaka, \%34,1) daha sık idi $(\mathrm{p}=0.001)$.

\section{METASTATIK TÜMÖRLER}

Tüm tümörler içerisinde $65(\% 24,4)$ vaka metastatik tümör idi. Metastatik tümörlerin primer kaynakları bașta akciğer olup (26 vaka $\% 9,8)$, bunu meme $(10$ vaka $\% 3,8)$ ve kolon (8 vaka \%3) takip etmekte idi. 15 (\%23) olguda primer tümör kaynağı saptanamadı. Metastatik tümörlerin cinsiyete göre dağılımına bakıldığında erkeklerde daha sık görüldüğü saptandı $(\mathrm{p}=0.001)$. Metastatik tümörlerin primer kaynaklarına göre cinsiyetlerdeki dağılımına bakıldığında, kadınlarda en sık meme tümörü metastazı görülürken, erkeklerde en sık akciğer ve kolon tümörü metastazları saptandı (Tablo IV). Metastatik tümörlerin 10'lu yaş gruplarına göre dağılımına bakıldığında 60'lı yaşlarda pik yaptığı, 50'li ve 70'li yaşlarda daha az sayıda olmakla birlikte diğer yaş gruplarına göre daha sık görüldüğü saptandı (Tablo V). Metastatik tümörlerin primer kaynağının lokalizasyona göre dağılımına bakıldığında; akciğer ve kolon en sık serebellumda, meme tümör metastazı en sık pariyetal lobda görüldü. Metastatik tümörlerin lateraliteye göre dağılımına bakıldığında 47'sinin sağda, 18'nin solda yerkeşimli olduğu görüldü ( $\mathrm{p}=0.087)$.

\section{TARTIŞMA}

Bu çalışmada, 2008'den 2017 yılına kadar 3. basamak bir hastane kaylt sisteminden elde edilen 266 SSS tümörünün analizi sunulmaktadır. Elde edilen veriler yaş, cinsiyet, histoloji, lokalizasyon, grade ve lateraliteye göre varyasyon sıklığını ayrıntılı olarak analiz etmemize olanak sağlamaktadır. Bu çalışma ile Aydın ve çevresinde SSS tümörlerinin ilk istatistiksel raporu ve klinikopatolojik özellikleri sunulmaktadır. Çalışmanın temel amacı, Aydın ve çevresi popülasyonda SSS tümörlerinin dağılımını göstermek, literatür verileri ile karşılatırmaktır.

Bu çalışmada SSS tümörlerinin tanısında genel ortalama yaş 60,47 idi. Diğer popülasyonlara bakıldığında Avrupa verilerinde ortalama yaş 5324 iken, Amerika verilerinde 6016 idi. Bu seride ortalama yaşın Amerika verilerine daha yakın olduğu görüldü. Dünya geneli raporlara bakıldığında SSS tümörlerinin sıklığının yaşla birlikte arttığı görülmüștür. SSS tümörlerinin yetişkinlerde 40 'lı yaşlardan itibaren artış gösterip, sıklıkla 50-69 yaş grubunda en yüksek sayılara ulaştığı saptanmıştır ${ }^{25}$. Bu sonuçlar ülkemize ait çalışma sonuçları ${ }^{20,21}$ ve mevcut literatür bilgileri ile uyumlu olup, bu veri çeşitli ulusal kanser kayıtlarının beyin tümörleri epidemiyolojisindeki desteklemektedir ${ }^{13}$.

SSS tümörlerinin tüm tipleri her iki cinsiyette de görülebilir. CBTRUS istatistik raporuna göre tüm primer SSS tümörlerinde vakaların ortalama \%42'si kadın, \%58'i erkek olarak bildirilmiştir ${ }^{16,23}$. Ülkemize ait benzer bir çalışmada ise SSS tümörlerinin \%40,8'i kadın olup, \%59,2'si erkektir20. Bu çalışmada vakaların \%49,2'si kadın, \%50,8'i erkek olup, tüm SSS tümörlerinin cinsiyete göre dağılımında anlamlı bir farklılık bulunmadı. Raporlarda primer SSS tümör tiplerinin cinsiyet dağılımında bazı farklılıklar olduğu görülmektedir. Özellikle nöroepitelyal tümörler erkeklerde daha sık iken, meningiomlar ve hipofiz adenomları kadınlarda daha sık gözlenmektedir ${ }^{16,25}$. Ülkemize ait benzer bir çalışmada ise nöroepitelyal tümörlerin büyük bir kısmı erkeklerde gözlenirken, kadınlarda en sık görülen tümör meningiom idi ${ }^{20}$. Bu çalışmada meningiom sıklığı, kadınlarda erkeklere göre anlamlı olarak daha fazlaydı. Bu sonuç, Asya, Avrupa ve Amerika'daki diğer çalışmalarla tutarlılık göstermekteydi13,26,27. Ayrıca bu çalışmada ülkemiz popülasyonunda yapılan bir çalışmaya ${ }^{20}$ benzer olarak, malign 
tümörlerin daha çok erkeklerde, benign tümörlerin daha çok kadınlarda görüldüğü saptandı. Batı popülasyonlarına ait vaka serilerinde de benzer cinsiyet farklılıkları mevcut idi16,28. Bu durum cinsiyete bağl hormonal değişikliklerin ve yaşam tarzlarının bu sonuca katkıda bulunabileceğini göstermektedir. Daha zararlı ve stresli yaşam tarzını düzeltmenin özellikle erkeklerde görülen malign SSS tümörlerinin sıklığını azaltabileceğini düşündürmektedir ${ }^{29}$. Avrupa ve Asya vaka serilerinde ve ülkemize ait bir çalışmada primer SSS tümör gruplarına bakıldığında nöroepitelyal tümörler en büyük kategoriyi oluşturmakta, bunu meningiomlar ve hipofiz adenomları takip etmektedir 2,13,20,26. CBTRUS'nden elde edilen istatistiksel raporda primer SSS tümör gruplarının insidans oranlarına bakıldığında meningiomlar en büyük tümör grubu olup, nöroepitelyal tümörler, sellar bölge tümörleri, kranial sinir tümörleri bunu takip eden yüksek oranlara sahip gruplardır ${ }^{16}$. Yine Japonya'da prevalansı en yüksek grup meningiomlardır ${ }^{30}$. Bu çalışmada da nöroepitelyal tümörler en yaygın grup olup, bunu sirasiyla meningiomlar, sellar bölge tümörleri takip etmekte idi. Popülasyonlar arası bu farklılıkların nedeni tam olarak bilinmemekte olup, bunun için daha geniş çalışmalara ihtiyaç vardır. Yapılan epidemiyolojik çalışmalarda nöroepitelyal tümörlerin insidans oranlarının ülke, ırk, tanı yaşı, cinsiyet ve histolojik tipe göre anlamlı farklılıklar gösterdiği belirtilmiștir ${ }^{31}$. Kanser etyolojisi komplekstir ve çok sayıda risk faktörü kanser gelişiminde etkilidir. Yaşam tarzı farklılıkları, beslenme alışkanlıkları, çevresel maruziyet vb. farklı toplumlardaki insanlarda beyin tümörü riskini anlamak için değerlendirilen birçok faktör arasındadır ${ }^{23}$. Bu çalışmada nöroepitelyal tümörlerin histolojik tiplere göre dağılımına bakıldığında glioblastom en sık görülen tip olup, bunu diffüz astrositom ve anaplastik astrositom takip etmekteydi. $\mathrm{Bu}$ sonuçlar CBTRUS istatistik raporu ve diğer geniş vaka serili raporlar ile uyumlu idi7,16,22,32. Günümüzde yaygın olarak görülen nöroepitelyal tümörlerin çoğunluğu kötü prognozlu yapıya sahiptir; bu nedenle çok miktarda klinik ve araştırma kaynağının bunlara yatırılmasının nedeni budur ${ }^{29}$. Glioblastom ve anaplastik astrositomun tüm primer SSS tümörleri içerisinde oranı \%20-50 arasında değişmektedir ${ }^{16,25}$. Bu çalışmada primer SSS tümörlerinin histolojik tiplere göre dağılımına bakıldığında en sık görülen tümör tipinin meningiomlar olduğu bunu sirasiyla glioblastomlar ve hipofiz adenomlarının takip ettiği görüldü. Literatürde benzer sonuçlar bulan vaka serileri mevcuttur 10,13,32,33. CBTRUS raporunda en sık bildirilen histolojik tip meningiom $(\% 37,1)$ olup, ardından hipofizin tümörleri $(\% 16,5)$ ve glioblastom $(\% 14,7)$ gelir. Malignite durumlarına göre bakıldığında ise hem bu çalışmada, hem de CBTRUS raporunda malign tümörler içerisinde en sık görülen tümör tipi glioblastom olup, malign olmayan tümörler içerisinde en sı görülen tip ise meningiomdur ${ }^{16}$. Bazı çalışmalarda ise yetişkinlerde primer SSS tümörlerinde en sık gözlenen histolojik tipler sırasıyla glioblastom, anaplastik astrositom, meningiom ve hipofiz adenomudur ${ }^{20,25}$. Meningeal tümörler dünya genelinde artış göstermektedir, tanısal teknolojideki gelişmeler bu durumun majör sebebi gibi görünmektedir 5 .

Yapılan çalışmalarda erişkinlerde intrakranial tümörlerin büyük çoğunluğunun supratentoriyal yerleşimli olduğu ve en sık tutulan lokalizasyonların ise sirasıyla frontal, temporal ve pariyetal loblar olduğu saptanmıștır2,13,20. Yine CBTRUS raporunda tümörlerin \%61,2'sinin supratentoriyal yerleşimli olduğu ve büyük çoğunluğunun frontal $(\% 8,2)$, temporal $(\% 6,0)$, pariyetal $(\% 3,5)$ ve oksipital loblar $(\% 1,0)$ tuttuğu bildirilmiştir ${ }^{16}$. $\mathrm{Bu}$ çalışmada da mevcut literatür ile uyumlu bulgular elde edilmiştir. Literatürde SSS tümörlerinin lateraliteye göre 
dağılımını değerlendiren çok az çalışma mevcuttur. Jafarzadeh ve ark.13 yaptıkları çalışmada SSS tümörlerinin sağ ve sol yerleşimli olma oranlarında anlamlı bir fark saptamamışlardır. $\mathrm{Bu}$ çalışmada tümörlerin lateralite durumuna göre dağılımına bakıldığında sağ taraf tutulumunun anlamlı bir şekilde daha fazla olduğu saptandı $(p=0,001)$. Yine aynı çalışmada bu çalışmadakine benzer şekilde, düşük dereceli meningiom ve gliomların daha çok sol yerleşimli, yüksek dereceli gliomların daha çok sağ yerleșimli olduğunu saptanmıştır ${ }^{13}$.

Grade tümörlerin biyolojik davranışlarını ve nüks olasılıklarını öngören, tedavi ve prognozu belirleyen önemli bir veridir ${ }^{6}$. DSÖ SSS tümörleri sinıflamasında tümörlerin histopatolojik tipleri ve gradeleri birlikte yer almaktadır. Grade I tümörler, sadece cerrahi yaklaşımla tamamen iyileşebilen, düşük proliferasyon potansiyeline sahip tümörlerdir. Grade II tümörler, genel olarak düşük proliferasyon potansiyeline sahip olmasına rağmen, nüks edebilme ve zaman içinde yüksek dereceli tümörlere ilerleyebilme kapasitesine sahiplerdir. Grade III tümörler, morfolojik olarak anaplastik özellikler taşır, yüksek nüks edebilme özelliğine sahiptir, ayrıca kemoterapi ve radyoterapi gibi ek tedavi yöntemlerine ihtiyaç duyarlar. Grade IV tümörler ise en malign morfolojik özellikleri taşıyan, hızla nüks etme özelliğine sahip, hastalar açısından en kötü prognozlu tümörlerdir 5,10. SSS'de grade I tümörlerin büyük çoğunluğunu meningiomlar oluştururken, en sik izlenen grade IV primer malign tümör glioblastomdur. Yapılan çalışmalarda grade I en yaygın grup olarak saptanmıştır ${ }^{2,7}$. Grade'in cinsiyete göre dağılımında ise meningiom başta olmak üzere grade I ve II tümörlerin daha çok kadınlarda, yine glioblastom bașta olmak üzere grade III ve IV tümörlerin erkeklerde daha sık görüldüğü rapor edilmiştir ${ }^{5,16}$. $\mathrm{Bu}$ çalışmada grade dağılımına göre elde edilen veriler literatür ile uyumlu idi.

Metastatik tümörler erişkin popülasyonda intrakranial tümörlerin çoğunluğunu oluşturur, insidansı \%8-10 arasındadır, literatürde kanserli tüm hastalarda ortalama \%10-20 arasında oran bildirilmiştir ${ }^{5,7,8}$. Otopsi serilerinde kanserden ölen hastaların yaklaşık \%25'inde beyine metastaz mevcuttur8. Bu insidans oranları primer lezyona bağlı olarak değişme eğilimindedir. Bizim çalıșmamızda metastatik tümörler tüm SSS olgularının \%24,4'ünü oluştururken, ülkemiz popülasyona ait başka bir çalışmada bu oran \%16,7 olarak bildirilmiştir ${ }^{20}$. Beyin tümörü metastazlarının literatürde bildirilen insidans oranları, yetersiz patolojik tanı ve raporlama sebebiyle gerçek insidans oranından muhtemelen daha düşüktür ${ }^{9}$. Geçen zaman içerisinde metastatik tümörlerin oranında artış görülmüştür. Kanser hastalarında tümör yayılımının daha etkili takip edilmesi ve daha ileri teknolojide görüntüleme yöntemlerinin kullanılması bu artışa katkıda bulunmaktadır ${ }^{8}$. Dünya genelinde metastatik tümörlerin insidansındaki artış, bu grubun çalışmamızda SSS tümör grupları dağılımında 3 . sıraya yerleşmesinin kanıtıdır. Çeşitli primer tümörlerin dağılımlarında cinsiyetler arası farklılıklar bulunurken, bu tümörlerin beyin metastazlarında cinsiyetler arasında anlamlı bir faklılık saptanmamıştır9. Bu çalışma da dahil, bazı çalışmalarda ise erkeklerde anlamlı olarak daha sık görüldüğü saptanmıştır ${ }^{32,33}$. En yaygın beyin metastazı primer kaynağı özellikle adenokarsinom ve küçük hücreli karsinom alt tipini içeren akciğer kanseridir. Bunu meme kanseri, melanom, renal hücreli karsinom ve kolorektal kanser takip eder,9. Metastatik intrakranial tümörler en sık görülen nöroepitelyal tümörlerden bile daha çeşitlidir. Metastatik tümörlerde görülen farklılıklar popülasyonlarda tanımlanan primer tümör tipleri ve mutasyonlara bağlı olarak değişmektedir ${ }^{32}$. Olguların yaklaşık \%10'unda 
metastaz kaynağı belirlenememektedir ${ }^{8,9}$. Bu çalışmada metastatik tümörlerin primer kaynaklarına göre dağılımında en sık akciğer, meme ve kolon tümörleri saptanmış olup, metastatik tümör olgularının yaklaşık $1 / 4$ 'üne yakınında primer tümör kaynağı belirlenememiştir. Genel olarak intrakranial metastazların yaklaşık \%80'i serebral hemisferlerde lokalize olup, kalanın \%15'i serebellumda, $\% 5^{\prime} \mathrm{i}$ ise beyin sapında görülür8,9,13,16. $\mathrm{Bu}$ çalışmada metastatik tümörlerin yaklaşık \% 75 'i serebral hemisferde, $\% 25$ ' ise serebellumda izlenmiş olup, anatomik lokalizasyona göre dağılımına bakıldığında serebellumda daha sık görülmesi istatistiksel olarak anlamlı bulunmuştur.

SSS tümörleri insidansı gelişmiş batı ülkelerinde daha yüksek oranda görülmekle birlikte, dünya genelinde büyük ölçüde değişmektedir ${ }^{13,16}$. Aydın ve çevresi bölgeyi kapsayan bu vaka serisinde primer SSS tümörlerinin cinsiyet, anatomik lokalizasyon, grade dağılımlarının dünya geneli literatür ile uyumlu olduğu, tümörlerin Amerika verilerine benzer şekilde, Asya ve Avrupa popülasyonuna göre ise daha ileri yaşta görüldüğü saptanmıştır. SSS tümör grupları ve histolojik tiplere göre dağılımında ise Asya ve Avrupa verilerine daha yakın sonuçlar elde edilmiştir. Tümörlerin lateralite durumuna göre dağılımında literatürden farklı olarak anlamlı bir şekilde sağda daha sık olduğu görülmüştür. Metastatik tümörlerin tümör kaynak tipleri ve dağılımı literatür ile uyumlu bulunmuş olup, en sık tuttuğu lokalizasyonun serebellum olması ve cinsiyete göre dağılımında erkeklerde daha sık olması literatürden farklı elde ettiğimiz sonuçlardır. Sonuç olarak, ülkemizde SSS tümörlerinin dağılımı hakkında sadece birkaç çalışma bildirilmiştir. Özellikle, Aydın ve çevresi epidemiyolojik verileri sunan bir çalışma yapılmamıştır. Hastaneye dayalı retrospektif bir çalışma olan bu çalışma, Aydın ve çevresi SSS tümörlerinin önemli epidemiyolojik özellikleri ve uluslararası serilere kıyasla nasıl dağılım gösterdiğini anlamaya yardımcı olmaktadır. Ancak, bu veriler yalnızca tek merkez istatistikleridir ve diğer kurumlarla ișbirliği yapmak, bu tümörler hakkındaki bilgimizi ulusal düzeyde artırmak için çok önemlidir. Ayrıca önemli hastalık ve ölüm oranlarına neden olan bu tümör grubunun nedenleriyle ilgili araştırmalar, klinik denemeler, hastalığı önleme ve kontrol programlarmın tahsis edilmesi ve planlanması için önemli bilgiler sağlar.

Etik Kurul Kararı: Bu çalışma, Aydın Adnan Menderes Üniversitesi Hastanesi Girişimsel olmayan klinik araştırmalar etik kurulunda 2019/17 protokol no ile onaylanmıștır.

Çıkar Çatışması Beyanı: Yazarlar çıkar çatışması olmadığını bildirmişlerdir.

Finansal Destek: Bu çalışma her hangi bir fon tarafından desteklenmemiştir.

Declaration of Conflicting Interests: The authors declare that they have no conflict of interest.

Financial Disclosure: No financial support was received.

\section{KAYNAKLAR}

1. Ostrom QT, Gittleman H, Fulop J et al. CBTRUS statistical report: primary brain and central nervous system tumors diagnosed in the United States in 2008-2012. Neuro Oncol. 2015;17 Suppl 4: 41-462.

2. Hernández-Hernández A, Reyes-Moreno I, Gutiérrez-Aceves A, et al. Primary Tumors of the Central Nervous System. Clinical Experience at a Third Level Center. Rev Invest Clin. 2018; 70: 177-83.

3. Ostrom QT, Gittleman H, Xu J, et al. CBTRUS statistical report: primary brain and other central nervous system tumors diagnosed in the United States in 2009-2013. Neuro Oncol. 2016; 18: 51-575. 
4. Naser RK, Hassan AA, Shabana AM, Omar NN. Role of magnetic resonance spectroscopy in grading of primary brain tumors. Egypt J Radiol Nucl Med. 2016; 47: 577-84.

5. Louis DN, Ohgaki H, Wiestler OD, et al. WHO classification of tumours of the central nervous system. Revised 4th ed. Lyon: IARC, 2016: 5-18.

6. Ocak GAG, Gürer İE. Pathology and Classification of Brain Tumors. Turkiye Klinikleri J Radiol-Special Topics 2017; 10: 1107.

7. Nibhoria S, Tiwana KK, Phutela R, et al. Histopathological spectrum of central nervous system tumors: A single centre study of 100 cases. İnternational Journal of Scientific study. 2015; 3: 130-4.

8. Gavrilovic IT, Posner JB (2005). Brain metastases: epidemiyology and pathophysiology. J Neurooncol. 75: 5-14.

9. Wesseling P, von Deimling A, Aldape KD et al. Metastatic tumours of the Central Nervous System. İn: Louis DN, Ohgaki H, Wiestler OD, Cavenee WK, Ellison DW, Branger DF eds. WHO classification of tumours of the central nervous system. Revised 4th ed. Lyon: IARC, 2016: 33841.

10. Louis DN, Ohgaki H, Wiestler OD, Cavenee WK (eds). WHO Classification of tumours of the central nervous system. 4th ed. Lyon: IARC, 2007.

11. DeAngelis LM. Brain tumors. N Engl J Med. 2001; 344: 114-23.

12. Louis DN, Ohgaki $\mathrm{H}$, Wiestler OD et al. The 2007 WHO classification of tumours of the central nervous system. Acta Neuropathol. 2007; 114: 97-109.

13. Jafarzadeh $\mathrm{N}$, Faal $\mathrm{A}$, Izanloo $\mathrm{A}$, et al. Epidemiology of Nervous System Tumors According to WHO 2007 Classification: A Report of 1,164 Cases from a Single Hospital. Int J Cancer Manag. 2018; 11: 114-62.
14. Hema NA, Ravindra RS, Karnappa AS. Morphological Patterns of Intracranial Lesions in aTertiary Care Hospital in North Karnataka:A Clinicopathological and Immunohistochemical Study. J Clin Diagn Res. 2016 Aug; 10: 1-5.

15. Barnholtz-Sloan JS. Brain and central nervous system tumor statistics: access to accurate data for all countries is critical! Neuro Oncol. 2019; 21: 291-2.

16. Ostrom QT, Gittleman H, Truitt G, et al. CBTRUS Statistical Report: Primary Brain and Other Central Nervous System Tumors Diagnosed in the United States in 2011-2015. Neuro Oncol. 2018; 20: 1-86.

17. Zhang AS, Ostrom QT, Kruchko C, et al. Complete prevalence of malignant primary brain tumors registry data in the United States compared with other common cancers, 2010. Neuro Oncol. 2016; 19: 726-35.

18. Ferlay J, Soerjomataram I, Dikshit R et al. Cancer incidence and mortality worldwide: Sources methods and major patterns in GLOBOCAN 2012 Int. J. Cancer. 2015; 136: 35986.

19. Howlader N, Noone AM, Krapcho M, et al. eds: SEER Cancer Statistics Review, 1975- 2011. Bethesda, Md: National Cancer Institute, 2014.

20. Gün BD, Bahadır B, Numanoğlu G, ve ark. Zonguldak Karaelmas Üniversitesi Tıp Fakültesi Patoloji Anabilim Dalı'nda 2002-2006 yılları arasında tanı alan sinir sistemi tümörleri. Türk Patoloji Dergisi 2007; 23: 93-7.

21. Haydaroğlu A, Bölükbaşı Y, Özsaran Z. Ege Üniversitesi'inde kanser kayit analizleri: 34134 olgunun değerlendirmesi. Türk Onkoloji Dergisi 2007; 22: 22-8.

22. Ostrom QT, Gittleman H, Farah $P$ et al. CBTRUS statistical report: Primary brain and central nervous system tumors diagnosed in the United States in 2006-2010. Neuro Oncol 2013; 15: 1-56. 
23. Jaiswal J, Shastry AH, Ramesh A, et al. Spectrum of primary intracranial tumors at a tertiary care neurological institute: A hospitalbased brain tumor registry. Neurol India. 2016; 64: 494-501.

24. Crocetti E, Trama A, Stiller C et al. Epidemiology of glial and non-glial brain tumours in Europe. Eur J Cancer. 2012; 48: 1532-42.

25. Materljan E, Materljan B, Sepcic J, et al. Epidemiology of central nervous system tumors in Labin area, Croatia, 1974- 2001. CMJ 2004; 45: 206-12.

26. Wiemels J, Wrensch M, Claus EB. Epidemiology and etiology of meningioma. J Neurooncol. 2010; 99: 307-14.

27. Michaud DS, Gallo V, Schlehofer B et al. Reproductive factors and exogenous hormone use in relation to risk of glioma and meningioma in a large European cohort study. Cancer Epidemiol Biomarkers Prev. 2010; 19: 2562-9.

28. Gomes J, Al Zayadi A, Guzman A. Occupational and environmental risk factors of adult primary brain cancers: a systematic review. Int J Occup Environ Med. 2011; 2: 82111.
29. Wang X, Chen JX, Zhou Q et al. Statistical Report of Central Nervous System Tumors Histologically Diagnosed in the Sichuan Province of China from 2008 to 2013: A West China Glioma Center Report. Ann Surg Oncol. 2016 Dec; 23: 946-53.

30. Nakamura H, Makino K, Yano S, Kuratsu J, Kumamoto Brain Tumor Research Group. Epidemiological study of primary intracranial tumors: a regional survey in Kumamoto prefecture in southern japan 20 year study. Int J Clin Oncol. 2011; 16: 314-21.

31. Ostrom QT, Bauchet L, Davis FG et al. The epidemiology of glioma in adults: A "state of the science" review. Neuro Oncol 2014; 16: 896913.

32. Stoyanov GS, Sarraf JS, Matev BK et al. A Comparative Review of Demographics, Incidence, and Epidemiology of Histologically Confirmed Intracranial Tumors in Brazil and Bulgaria. Cureus. 2018; 10: e2203.

33. Stoyanov GS, Dzhenkov DL, Kitanova M et al. Demographics and incidence of histologically confirmed intracranial tumors: a five-year, twocenter prospective study. Cureus. 2016; 9: e1476. 